Original Research Paper

\title{
Pemanfaatan Tanaman Lokal Sebagai Pewarna Alami Tenun Tradisional Sembalun Lawang
}

\author{
M. Sarjan ${ }^{1}$, Baiq. Rara Ulansari ${ }^{2}$, Dara Fitriana ${ }^{3}$, Witanti Sukma $\mathbf{K}^{4}$ \\ ${ }^{\text {I} P a s c a s a r j a n a, ~ U n i v e r s i t a s ~ M a t a r a m, ~ M a t a r a m, ~ N u s a ~ T e n g g a r a ~ B a r a t, ~ I n d o n e s i a ; ~}$ \\ ${ }^{2}$ S1 Peternakan, Fakultas Peternakan, Universitas Mataram, Mataram, Nusa Tenggara Barat, Indonesia; \\ ${ }^{3}$ Akuntansi, Fakultas Ekonomi, Universitas Mataram, Mataram, Nusa Tenggara Barat, Indonesia; \\ ${ }^{4}$ Pendidikam Kimia, FKIP, Universitas Mataram, Mataram, Nusa Tenggara Barat, Indonesia
}

https://doi.org/10.29303/jpmpi.v3i2.871

Sitasi: Sarjan, M., Ulansari, B. R., Fitriani. D., \& Sukma, W. S. K. (2021). Pemanfaatan Tanaman Lokal Sebagai

Pewarna Alami Tenun Tradisional Sembalun Lawang. Jurnal Pengabdian Magister Pendidikan IPA, 4(3)

\section{Article history}

Received: 15 Juli 2021

Revised: 31 Juli 2020

Accepted: 18 Agustus 2021

*Corresponding Author: M.

Sarjan, Pascasarjana,

Universitas Mataram, Mataram,

Nusa Tenggara Barat,

Indonesia;

Email: msarjan@unram.ac.id

\begin{abstract}
Kegiatan ini bertujuan mengkaji jenis-jenis tumbuhan lokal yang menjadi pewarna alami yang digunakan oleh penenun tradisional Sembalun di desa Sembalun Lawang Kabupaten Lombok Timur. Kajian meliputi jenis-jenis tumbuhan yang digunakan sebagai pewarna alami dan keberadaannya di alam sekitar tempat tinggal masyarakat. Penggunaan tumbuhan pewarna alami dalam tenun tradisional menambah nilai jual dan keunikannya terutama di pasar internasional. Hasil kegiatan menunjukkan bahwa penenun pewarna alami Sembalun yang dihasilkan dari ekstrak tumbuhan diantaranya seperti bagian daun bunga, dan biji yang menghasilkan beberapa komponen warna yaitu merah yang terbuat dari tumbuhan bayur (ptesterum javanicum), kuning terbuat dari kunyit (curcumalong), warna hijau ini dibuat dengan menggunkan tanaman mint (methaarvhensis) salah satu tanaman yang sangat banyak sekali ditemukan endemiknya khususnya di kecamatan Sembalun, kemudian warna ungu didapat dari ekstrak blueberry tanaman ini masuk dalam genus vaccinium sedangkan warna coklat itu sendiri didapat dari ekstrak kayu akasia yang menjadi salah satu pohon yang purba yang ada di Sembalun
\end{abstract}

Keywords: Pewarna alami; Tumbuhan lokal; Tenun tradisional; Sembalun Lawang.

\section{Pendahuluan}

Kecamatan di Kabupaten Lombok Timur yang memiliki luas wilayah $217,08 \mathrm{Km}^{2}$, terdiri dari 6 desa yaitu Desa Sembalun Bumbung, Desa Sembalun Lawang, Desa Sajang, Desa Bilok Petung, Desa Sembalun, dan Desa Sembalun Timba Gading. Ibu kota Kecamatan Sembalun berada di Desa Sembalun Lawang, yang berjarak sekitar 45 km dari ibu kota Kabupaten Lombok Timur (Selong). Sembalun Lawang adalah sebuah desa yang berlokasi di sebelah utara kaki Gunung Rinjani. Desa ini yang indah di ketinggian sekira $1.156 \mathrm{~m}$ ini menyuguhkan pemandangan alam yang indah sekaligus menjadi salah satu jalur populer titik awal pendakian ke Gunung Rinjani (3.726 m dpl). Selain Desa Sembalun Lawang, Desa Senaru adalah pintu gerbang lainnya untuk mencapai kemegahan Gunung Rinjani yang berlokasi di Pulau Lombok, Nusa Tenggara Barat.

Desa Sembalun Lawang merupakan salah satu desa wisata yang ada di pulau Lombok yang memiliki potensi dalam pengembangan ekowisata. Di daerah ini terdapat banyak fasilitas wisata yang bertambah seperti banyaknya tempat wisata yang menarik untuk dikunjungi, dan fasilitas yang ada di Sembalun Lawang yang dibangun karena wisatawan semakin bertambah seperti villa, homestay, kedai kopi, dll. Desa ini juga menjadi 
salah satu jalur pendakian menuju Bukit Anak Dara dan pendakian gunung Rinjani. Selain tempat wisata desa Sembalun Lawang juga memiliki budaya seperti gendang belek dan kerajinan tangan seperti kerajinan kain tenun.

Tenun merupakan Teknik pembuatan kain yang dibuat dengan prinsip yang sederhana yaitu dengan menggabungkan benang secara memanjang dan melintang dengan kata lain bersilangnya antara benang satu dengan benang yang lainnya secara bergantian. Tenun sebagai hasil kerajinan berupa kain dari bahan berupa benang yang dibuat dari (kapas, sutra, dsb). Widyati (2002):135. Biasanya produksi kain tenun dibuat dalam skala rumah tangga. Seni tenun berkaitan erat dengan sistem pengetahuan, budaya, kepercayaan, lingkungan alam, dan sistem organisasi sosial dalam masyarakat. Oleh sebab itu, seni tenun dalam masyarakat selalu bersifat partikular atau memiliki ciri khas, dan merupakan bagian dari representasi budaya masyarakat tersebut. Karena kultur sosial dalam masyarakat beragam, maka seni tenun pada masing- masing daerah memiliki perbedaan.

Pentingnya kerajinan tenun di Sembalun Lawang adalah untuk menambah pemasukan ekonomi dan melestarikan budaya sasak. Kerajinan tenun ini dijadikan tempat pariwisata oleh orangorang yang berkunjung ke Sembalun Lawang. Salah satu Dusun pengrajin kain tenun yang di produksi oleh Inaq Wenik. Inaq Wenik merupakan ketua kelompok dari pengrajin kain tenun dan memproduksi kain tenun dengan memanfaatkan tumbuhan tradisional sebagai pewarna alami. Tujuan Inaq Weniq menggunakan tumbuhan tradisional adalah untuk memanfaatkan bahan baku yang ada disekitar pekarangan rumah dan warna yang dihasilkan bagus, selain mengurangi biaya produksi pewarna alami ini juga aman, sehat dan bermanfaat bagi kesehatan tubuh. Pewarna alami adalah zat warna yang berasal dari ekstrak tumbuhan (seperti bagian daun, bunga, biji). Pewarna alami berasal dari tumbuhan mempunyai berbagai macam warna yang dihasilkan, hal ini dipengaruhi oleh beberapa faktor, seperti jenis tumbuhan, umur tanaman, tanah, waktu pemanenan dan faktor - faktor lainnya.
Permasalahan yang sering dialami Inaq Weniq yaitu mencari bahan-bahan yang akan dipakai untuk mewarnai. Contohnya kayu Pterocarpus Indicus (Ranting Angsana) dan Caesalpinia Sappan L (Sepang) karena keberadaanya yang ditengah hutan membuatnya lama untuk mendapatkan kayu tersebut. Supaya bisa mendapatkan kayu tersebut Inaq Weni harus pergi kehutan dan harus ditemani laki- laki. Selain itu, alat yang dipakai untuk proses pewarnaan (kompor gas) masih belum dimiliki sampai sekarang, Sehingga yang dipakai adalah tungku.

Proses pemasarannya, Inaq Weniq dan yang lain tidak bisa menggunakan sosial media yang menyebabkan orang-orang belum terlalu mengenal kerajinan kain tenun menggunakan pewarna alami, sehingga perlu ditingkatkan dengan mempromosikan kain tenun di sosial media.

Pernyataan dari inaq Wenik "Kain ini sering dipesan oleh konsumen yang berasal dari Jepang dan Singapura. Khususnya untuk konsumen yang berasal dari Jepang, kain ini sering digunakan sebagai syal saat olahraga. Dikatakan bahwa kandungan alami yang terdapat pada kain tenun sangat bagus untuk digunakan mengusap keringat setelah olahraga. Saat berkeringat, pori- pori terbuka sehingga apabila keringat diusap dengan kain tersebut, kandungan dalam kainnya yang merupakan bahan alami dapat terserap kedalam tubuh". Keunggulan pemakaian warna alam yaitu aman untuk lingkungan sekitar, tidak menyebabkan alergi kulit, menghasilkan warna yang soft, sumber daya alamnya bisa diperbarui dan Khas Indonesia. Keamanan dari penggunaan zat pewarna alami ini juga dibenarkan oleh Food and Drugs Administration (FDA) Amerika Serikat yang menggolongkan zat warna alami ke dalam golongan zat pewarna yang tidak perlu mendapat sertifikasi atau dianggap masih aman. Oleh karena itu penulis artikel ini perlu dilakukan agar dapat diperoleh data-data mengenai tumbuhan lokal yang dimanfaatkan sebagai bahan pewarna alami oleh masyarakat Sembalun Lawang. 


\section{Metode}

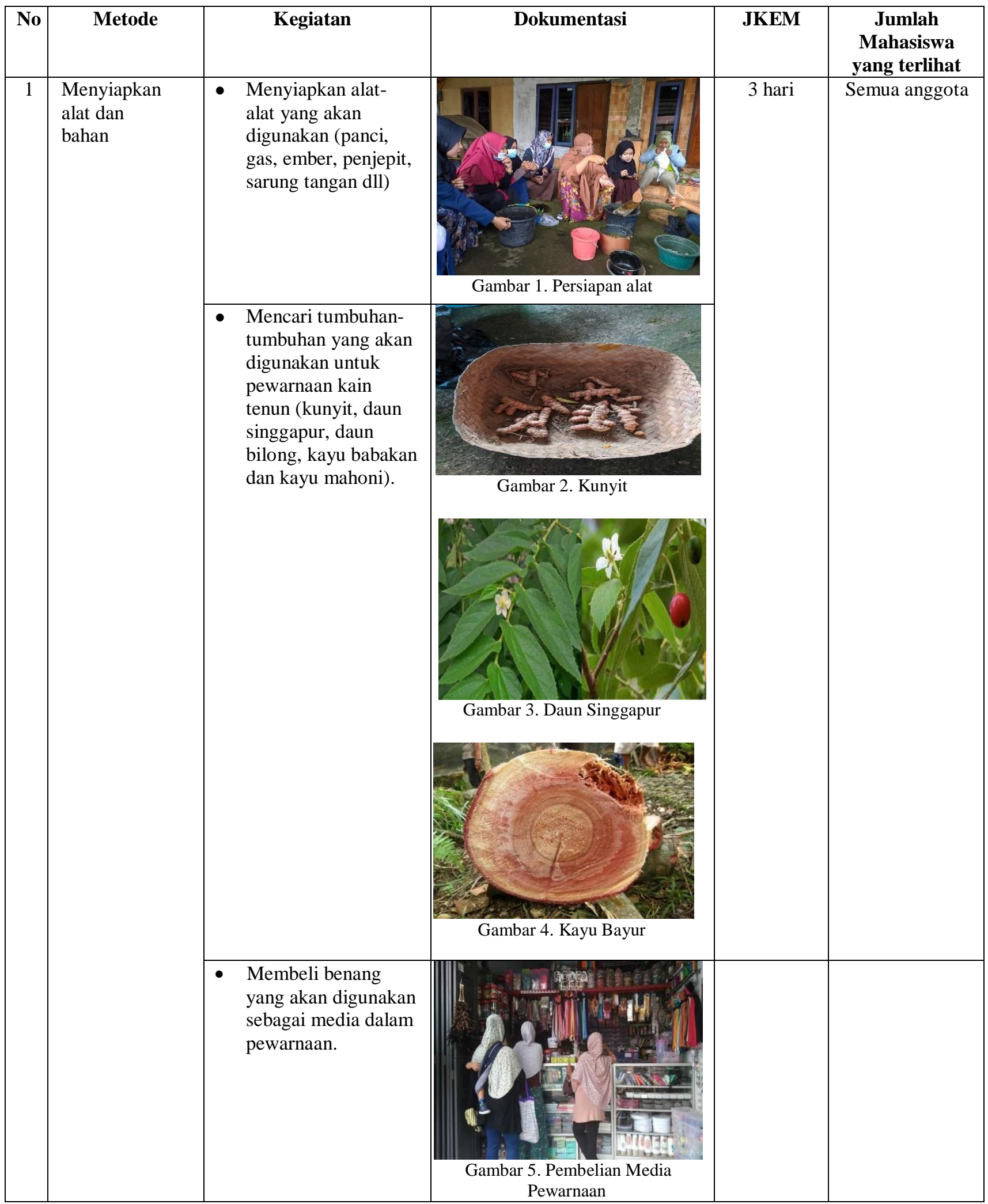




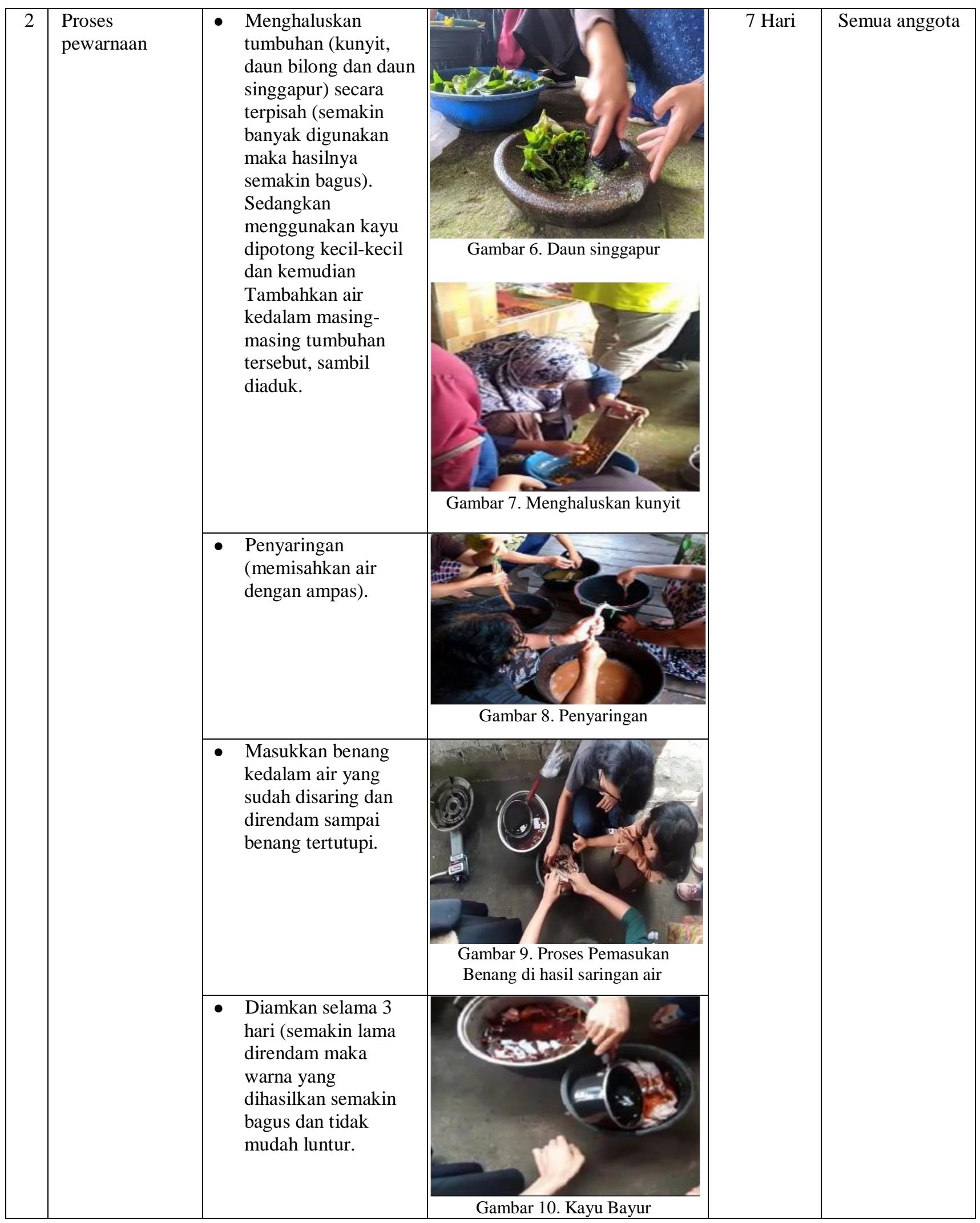




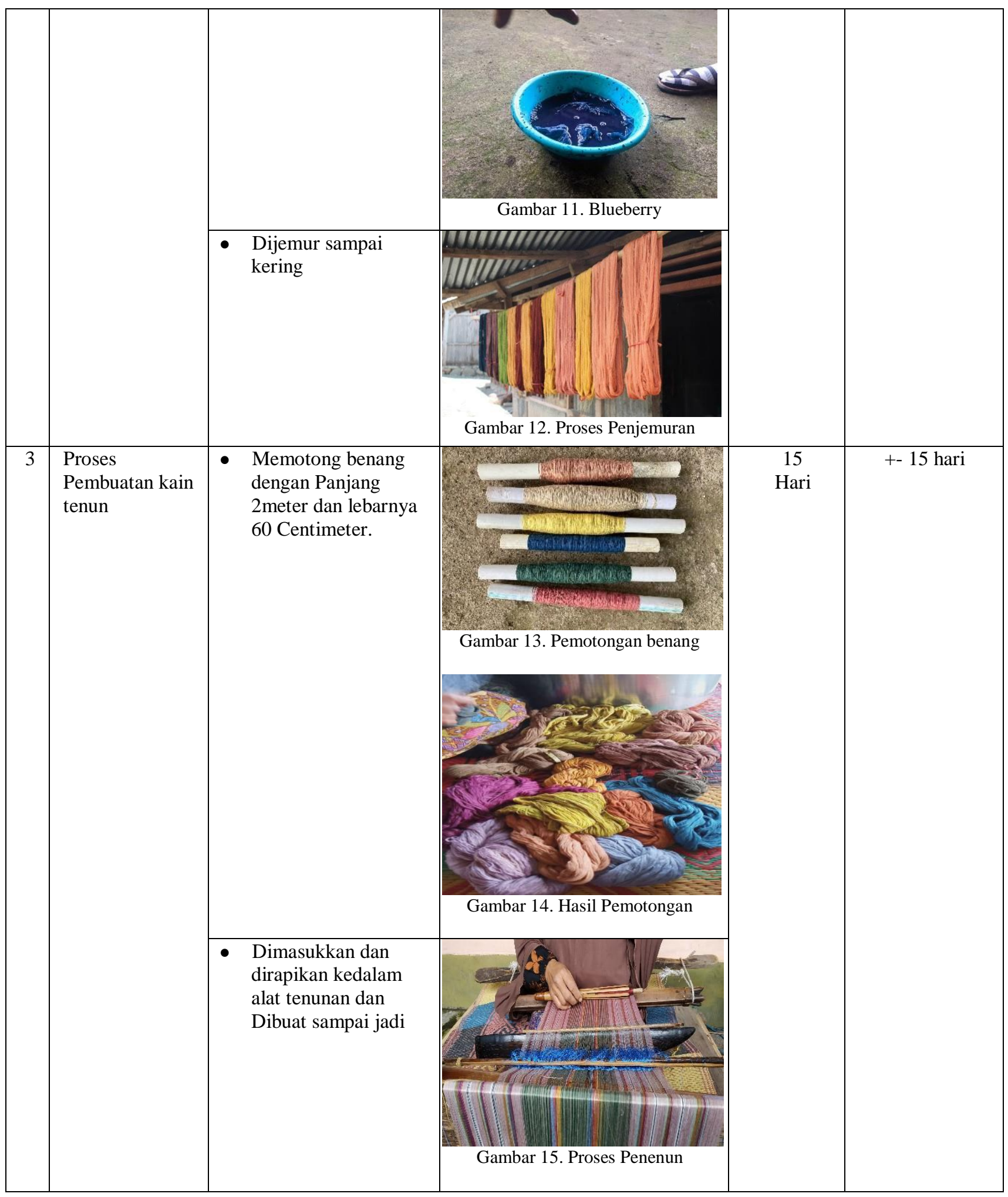




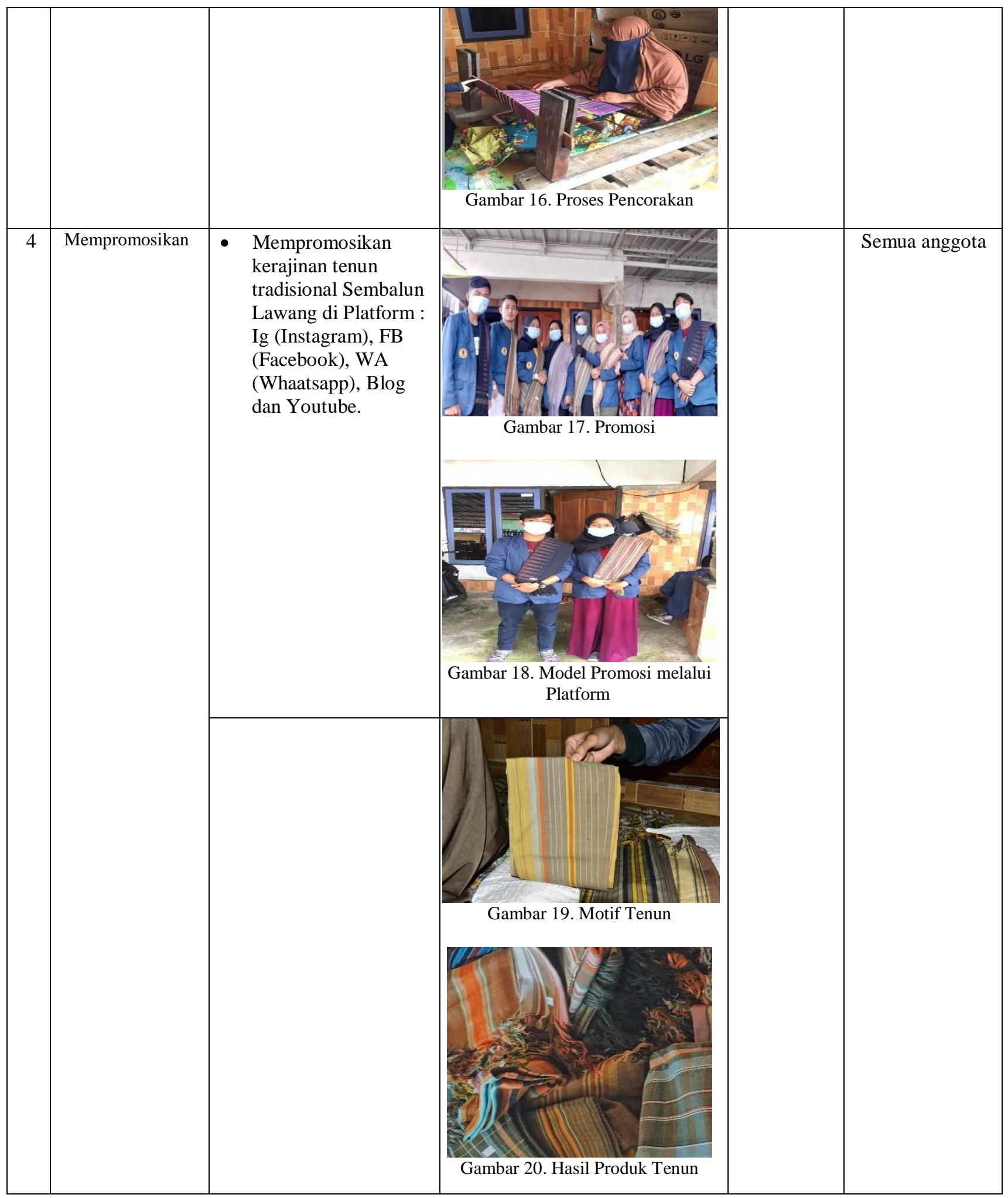




\section{Hasil dan Pembahasan}

A. Kelompok Tenun Pewarna Alami Tradisional Sembalun Lawang

Kelompok Tenun pewarna Alami Tradisional di Dusun Lebak Lauk Desa Sembalun Lawang Kecamatan Sembalun Kabupaten Lombok Timur Provinsi Nusa Tenggara Barat terdiri dari 30 orang yang dimana ketua kelompoknya yang bernama Inaq Wenik. Inaq Wenik mengatakan perkembangan pemasaran hasil produksi belum pesat sesuai yang diharapkan, untuk itu Inaq Wenik membutuhkan ruang- ruang untuk promosi salah satunya melalui sosial media. Rendahnya kerjasama dalam kelompok, rendahnya keterampilan dasar dan penguasaan Teknik yang variatif, rendahnya motivasi berusaha dan keterbatasan modal dalam berusaha menyebabkan kerajinan tenun tradisional sampai sekarang belum banyak diketahui sama orang.

Dugaan terhadap rendahnya kerjasama dan kekompakan antara sesama anggota dalam proses produksi hingga pemasaran, menyebabkan suatu kesimpulan untuk mengikat kerjasama dan kebersamaan anggota dalam menyelesaikan masalahnya. Melalui kelompok ini, akan memudahkan proses-proses yang harus dilakukan secara bersama. Melalui kelompok ini, diharapkan akan mewujudkan pemberdayaan pengrajin, sekaligus melanjutkan pertumbuhan usaha kerajinan. Berkembangnya kelompok tenun menjamin pendapatan, adanya pengembangan kemampuan serta adanya akses usaha dan kesempatan kerja yang lebih luas.

\section{B. Pewarna Alami Tenun Tradisional Sembalun Lawang}

Salah satu kekhasan kain tenun tradisional Sembalun Lawang adalah pewarnaan bahan dasar kainnya yang menggunakan zat pewarna alami. Dimana pewarna alami merupakan zat pewarnanya berasal dari ekstrak tumbuhan (seperti bagian daun, bunga, biji dan batang). Zat pewarna alami yang digunakan untuk mewarnai kain tenun Sembalun Lawang berasal dari tumbuhan tradisional yang tumbuh di sekitar wilayah Sembalun. Pewarna alami yang dihasilkan mempunyai berbagai macam warna yang dipengaruhi oleh beberapa faktor, seperti jenis tumbuhan, umur tanaman, tanah, waktu pemanenan dan faktor - faktor lainnya.
Berikut penjelasan warna- warna tenun Sembalun secara lebih spesifik:

\section{Merah}

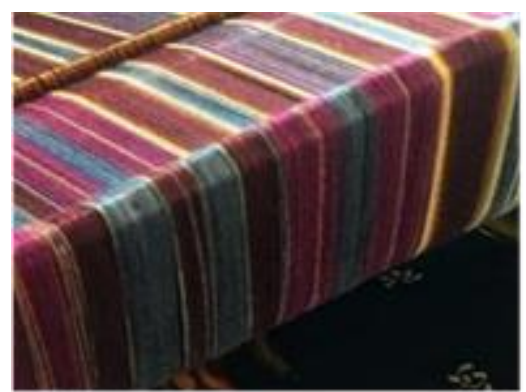

Gambar 21. Benang Merah hasil dari pewarnaan dengan pewarna alami ekstrak kulit bayur.

Ekstrak zat pewarna merah untuk kain tenun Sembalun Lawang di dapatkan dari tumbuhan bayur (pterospermum javanicum). Bayur merupakan tumbuhan yang biasa digunakan sebagai kayu pertukangan. Ciri-cirinya adalah kulit kayunya berwarna merah pucat, merah-coklat muda, hingga ke ungu unguan atau semu lembayung. Kayu gubalnya putih kotor hingga kelabu. Bagian kayu yang digunakan sebagai bahan pewarna merah alami adalah kulitnya. Kulit bayur tergolong sangat aman dan bagus sebagai bahan pewarna alami dikarenakan kandungan antioksidannya yang tinggi. Menurut kegiatan Saefudin et al. (2013) bahwa kulit batang dari tumbuhan bajur (pterospermum javanicum) memiliki kandungan antioksidan tertinggi dibandingkan spesies dari famili Sterculiaceae yang lain.

\section{Kuning}

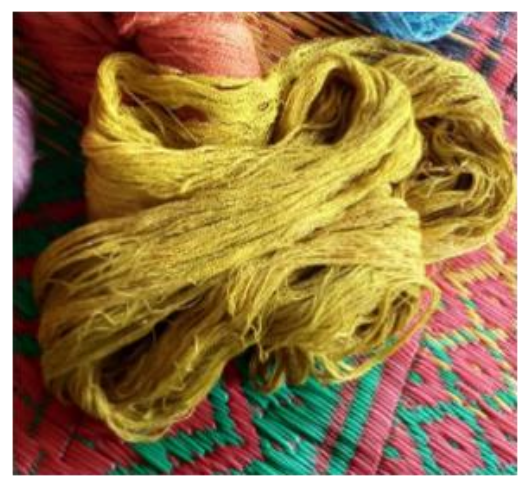

Gambar 22. Benang Kuning hasil dari pewarnaan dengan pewarna alami ekstrak kunyit. 
Ekstrak zat pewarna kuning untuk kain tenun Sembalun Lawang didapatkan dari tumbuhan kunyit (CurcumaLonga). Kunyit (Curcuma Longa) adalah salah satu tanaman yang sering digunakan oleh masyarakat indonesia sebagai penyedap masakan, bahan obat-obatan tradisional, kosmetik, jamu, dan juga pewarna. Ciri-ciri dari tanaman kunyit adalah batangnya semu, tegak, bulat, membentuk rimpang dan berwarna hijau kekuningan. Daunnya menyirip, berupa daun tunggal dan berwarna hijau pucat. Rimpangnya bercabang membentuk rumpun berbentuk bulat panjang dan berwarna kuning. Bagian dari kunyit yang digunakan sebagai pewarna alami kain tenun Sembalun Lawang adalah rimpangnya. Kunyit sangat aman dan sehat untuk digunakan sebagai bahan dari pewarna alami karena kandungan zat aktif yang terdapat pada kunyit memiliki efek farmakologis yang dapat digunakan sebagai pencegahan dan penyembuhan berbagai macam penyakit. Senyawa flavonoid yang terdapat dalam ekstrak kunyit berperan sebagai antioksidan, terpenoid sebagai anti bakteri, saponin sebagai Pereda batuk, dan alkaloid yang berperan sebagai analgesic dan anti mikroba. Keunggulan penggunaan kunyit sebagai pewarna alami untuk kain Tenun Sembalun juga karena aromanya yang sangat khas. Saat menggunakan kunyit sebagai pewarna alami, aroma yang tercium dari kain tenun akan sangat khas seperti aroma jamu yang segar.

\section{Hijau}

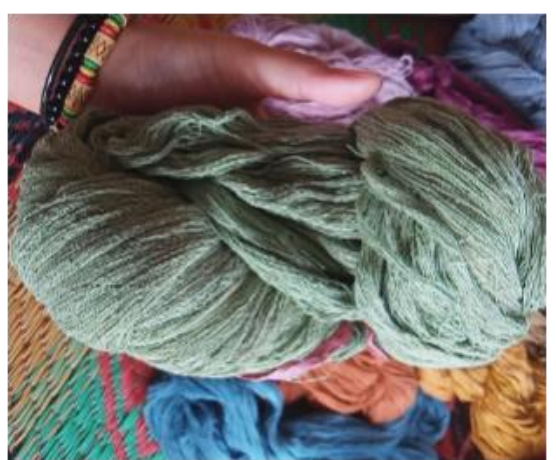

Gambar 23. Benang hijau hasil dari pewarnaan dengan pewarna alami daun pegagan.

Zat pewarna hijau untuk kain tenun Sembalun Lawang didapatkan dari berbagai macam dedaunan tumbuhan. Daun tumbuhan yang sering digunakan sebagai pewarna alami untuk kain tenun adalah daun mint, daun pecut kuda, dan daun pegagan.

Tanaman mint (Mentha Arvensis) adalah salah satu jenis tanaman mint yang tumbuh dengan baik pada daerah pegunungan yang bersuhu rendah contohnya seperti di Sembalun Lawang. Ciri-ciri dari tumbuhan ini adalah batangnya lunak berbulu dengan tinggi sekitar 30- $50 \mathrm{~cm}$, daunnya berbentuk bulat lonjong seperti telur yang menyirip dan bergerigi berwarna hijau. Bunganya berwarna ungu. Tanaman mint ini merupakan tanaman herbal tertua di dunia. Tanaman mint memiliki aktivitas antioksidan yang cukup tinggi sehingga dapat digunakan sebagai sumber antioksidan untuk penghambatan radikal bebas. Dengan manfaatnya tersebut, dapat dipastikan bahwa tanaman mint sangat aman dan baik apabila digunakan sebagai pilihan bahan pewarna alami kain tenun Sembalun Lawang.

Herba pecut kuda (stachytarpheta) adalah tumbuhan yang biasa tumbuh liar di tepi jalan, kebun-kebun, tanah lapang maupun tempat- tempat terlantar lainnya. Ciri-ciri dari tumbuhan ini adalah letak daunnya berhadapan, berbentuk bulat telur, bergerigi dan berwarna hijau tua. Tumbuh tegak, tinggi sekitar $50 \mathrm{~cm}$ dan bunganya duduk tanpa tangkai pada bulir-bulir yang berbentuk pecut berwarna ungu. Tumbuhan ini dimanfaatkan sebagai obat infeksi dan batu saluran kencing, rematik, sakit tenggorokan, pembersih darah, haid tidak teratur, keputihan, dan hepatitis A. Apabila dilihat dari manfaat dan khasiatnya, tumbuhan pecut kuda merupakan pilihan yang sangat baik untuk digunakan sebagai pewarna alami kain tenun Sembalun Lawang.

Daun pegagan (centella asiatica) merupakan tumbuhan herba tahunan yang tumbuhnya menjalar. Tumbuhan ini dapat dijumpai di area persawahan dan juga di sela sela rumput. Tempat yang sangat disukai oleh tumbuhan ini sebagai tempat tumbuhnya adalah tempat yang agak lembab dan terbuka. Ciri-ciri dari tanaman ini adalah mempunyai rimpang pendek, tanpa batang, panjangnya sekitar $10-80 \mathrm{~cm}$, tumbuh melata. Daunnya berbentuk ginjal, lebar, serta bundar dengan diameter sekitar 1-7 cm. pinggiran daunnya beringgit dan berwarna hijau. Kandungan yang terdapat pada daun pegagan dapat dimanfaatkan sebagai anti lepra dan juga penyembuh luka yang sangat baik. Sehingga pemilihan tumbuhan ini sebagai salah satu bahan pewarna alami untuk kain 
tenun Sembalun Lawang merupakan pilihan yang sangat baik.

\section{Ungu}

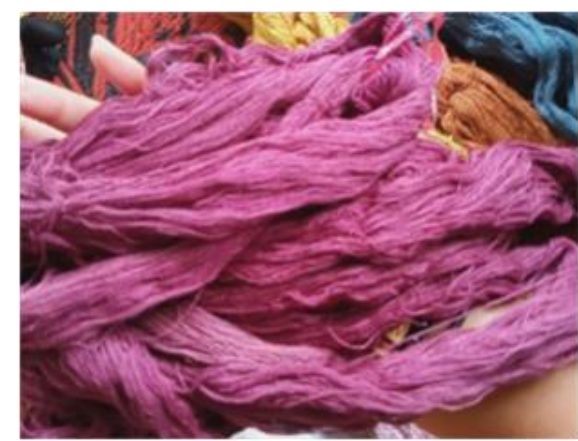

Gambar 24. Benang Ungu hasil dari pewarnaan dengan pewarna alami ekstrak Blueberry.

Ekstrak zat pewarna ungu didapatkan dari tumbuhan blueberry. Blueberry merupakan tanaman berbunga termasuk kedalam genus vaccinium, bagian Cyanococcus. Blueberry merupakan tanaman semak, memiliki ukuran mulai dari $10 \mathrm{~cm}-4 \mathrm{~m}$. daunnya berwarna hijau dan bunganya berbentuk bel, putih, merah, atau merah muda pucat. Blueberry mengandung potasium yang sangat bermanfaat untuk mengontrol tekanan darah, mencegah berkembangnya kerusakan vaskular ginjal, glomerulus dan tubulus, menurunkan resiko stroke, menurunkan ekskresi kalsium urin dan menurunkan demineralisasi tulang. Sehingga penggunaan buah blueberry sebagai pewarna alami kain tenun sangat baik dan aman bagi kesehatan.

\section{Cokelat}

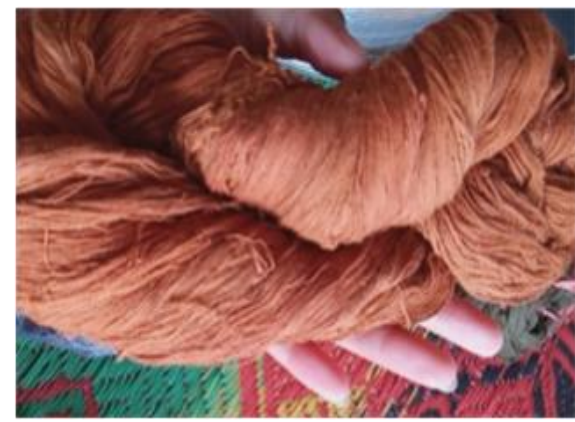

Gambar 25. Benang Cokelat hasil dari pewarnaan dengan pewarna alami ekstrak kulit kasia.

Ekstrak zat pewarna coklat didapatkan dari tumbuhan kunyit yang ditambahkan dengan ekstrak kayu akasia. Kayu akasia (Acacia mangium) merupakan pohon besar berbunga yang tumbuh mencapai ketinggian $30 \mathrm{M}$. pohon ini memiliki batang bebas cabang lurus yang panjangnya mencapai lebih dari setengah total tinggi pohon. Pohon akasia yang digunakan sebagai zat pewarna adalah bagian kulit pohonnya yang sudah tua karena saat muda kulit batang akan berwarna hijau dan untuk akasia tua warna kulit pohonnya akan berubah menjadi kecoklatan. Kayu akasia merupakan pilihan yang sangat baik untuk pewarnaan kain tenun karena kandungan kandungan tanin dari akasia dapat digunakan sebagai produk kecantikan kulit.

Untuk pengadaan warna lain selain warna yang sudah ditentukan di atas, para penenun mencampurkan ekstrak ekstrak zat warna tersebut. Seperti warna abu didapatkan dari ekstrak zat warna blueberry dan yang dicampurkan dengan tawas. Warna peach dihasilkan dari ekstrak pewarna kunyit (kuning) yang dicampurkan dengan kapur.

\section{Analisis Ekonomi}

Kain tenun dengan pewarna kimia jika dibandingkan dengan kain tenun pewarna alami memiliki perbedaan dari segi ekonomis, hal ini dikarenakan bahwa terdapat banyak perbedaan baik dari segi proses pembuatan pewarna maupun cara memperoleh bahan baku (pewarna). Pewarna kimia mudah didapatkan serta cara pengolahannya cukup mudah karena pewarna yang digunakan termasuk pewarna yang instan sehingga ketika proses pewarnaan kain tenun tidak memerlukan waktu yang lama dan proses yang tidak praktis. sedangkan untuk mendapatkan pewarna yang alami itu tidak mudah serta membutuhkan proses pewarnaan yang cukup lama.

Kain tenun dengan pewarna kimia cenderung memiliki ketahanan warna yang cepat memudar sedangkan kain tenun dengan pewarnaan alami memiliki ketahanan yang lama. Selain itu, kain tenun dengan pewarna kimia cenderung memiliki warna yang cerah atau mencolok. Lain halnya dengan kain tenun yang menggunakan pewarna alami memiliki warna yang cenderung lebih gelap dan menarik. Menurut Pak Widodo "guru Inaq Wenik yang merupakan salah satu pengrajin kain tenun di Dusun Lebak Lauk Desa Sembalun Lawang", kain tenun dengan pewarna alami memiliki keunggulan yaitu dari segi manfaatnya. 
Seperti ketika digunakan kain tenun bisa menyerap keringat, adem ketika digunakan serta apabila digunakan ketika berolahraga atau aktivitas yang bisa mengeluarkan keringat maka khasiat dari bahan alami akan masuk ke dalam tubuh, jadi kain tenun dengan bahan alami juga sangat baik bagi kesehatan.

Jika dilihat dari cara memperoleh bahan baku pewarna, maka dapat disimpulkan bahwa terdapat perbedaan harga yang relatif tinggi di antara kain tenun dengan bahan pewarna alami dan kain tenun dengan bahan pewarna kimia. Kain tenun dengan pewarna alami memiliki harga dikisaran Rp. 400.000,00 per 2 meter, sedangkan kain tenun dengan pewarna kimia memiliki harga kisaran Rp. 200.000,00 per 2 meter. Dari segi permintaan konsumen kain tenun dengan pewarna alami lebih banyak diminati dibandingkan dengan kain tenun dengan pewarna kimia, sehingga peluang untuk memproduksi kain tenun dengan pewarna alami memiliki prospek yang menjanjikan.

\section{Kesimpulan}

Dari pembahasan di atas dapat disimpulkan beberapa hal penting sebagai berikut:

1. Tumbuhan lokal yang dimanfaatkan sebagai bahan pewarna alami oleh masyarakat Sembalun Lawang yaitu tumbuhan bayur (pterospermum javanicum) sebagai pewarna merah, Kunyit (Curcuma Longa) sebagai ekstrak pewarna kuning, Tanaman mint (Mentha arvensis), Herba pecut kuda (Stachytarpheta) dan Daun pegagan (Centella asiatica) sebagai ekstrak pewarna hijau. Blueberry sebagai ekstrak pewarna ungu, dan Kayu akasia (Acacia mangium) sebagai ekstrak pewarna coklat.

2. Hasil tenun dari pewarna alami lebih unggul secara ekonomi dan ekologi dibanding dengan tenun dari pewarna kimia sintetis.

\section{Ucapan Terima Kasih}

Kami keluarga besar mahasiswa KKN Sembalun Lawang mengucapkan rasa terimakasih yang sedalam-dalamnya kepada semua pihak yang telah membantu dalam penyelesaian artikel ini.

\section{Daftar Pustaka}

https://www.forda.mof.org/index.php/berita/post/2604

https://www.google.com/amp/s/www.hestanto.web.id/ke rajinan-tenun- indonesia/amp/

https://www.google.comamp/s/www.mongabay.co.id/20 19//12/01/para-perempuan-lombok-pelestaritenun pewarna-alam/amp/

Sa'adah, Vina Savinatus, Ervizal A.M Zuhud dan Siswoyo. 2019. Potensi Pemanfaatan Tumbuhan Aromatik di Resort Kembang Kuning, Taman Nasional Gunung Rinjani, Nusa Tenggara Barat. Jurnal Media Konservasi(24)1:1 - 10.

Weniq. (2021). Kerajinan Tenun Lebak Lauk. Sembalun Lawang, Kecamatan Sembalun Kabupaten Lombok Timur Provinsi Nusa Tenggara Barat.

Widyati, R. 2002. Higiene dan Sanitasi Umum dan Perhotelan. Jakarta: PT Gramedia Widarsana Indonesia. 